\title{
Population structure and relative growth of the Amazon shrimp Macrobrachium amazonicum (Heller, 1862) (Decapoda: Palaemonidae) on two islands in the fluvial-estuarine plain of the Brazilian Amazon
}

Priscila Sousa Vilela da Nóbrega", Bianca Bentes and Jussara Moretto Martinelli-Lemos

(PSVN, JMML) Federal University of Pará (UFPA), Institute of Biological Sciences, Laboratory of Fisheries Biology and Management of Aquatic Resources, Research Group on Amazon Crustaceans Ecology - GPECA, Avenida Perimetral, 2651, Bairro Montese, 66077-530, Belém, Pará, Brazil. E-mail: (PSVN) priscila89vilela@hotmail.com / nobrega@ufpa.br; *Corresponding author (BB) Federal University of Pará (UFPA), Institute of Coastal Studies, Alameda Leandro Ribeiro s/n, 68600-000, Bragança, Pará, Brazil.

\begin{abstract}
This study aimed to describe the population structure of the Amazon shrimp Macrobrachium amazonicum, as well as their relative growth between the length of the cephalothorax and the total length, and between the length of the cephalothorax and the total mass of shrimps of a fluvial-estuarine plain in the State of Pará. Shrimps were sampled monthly from August 2006 to July 2007, using trawl nets, taking three replicates at each site (Arapiranga and Mosqueiro) per month, totaling 72 replicates. We caught 5,510 specimens, being $90.90 \%$ from Arapiranga Island and 9.1\% from Mosqueiro Island. The highest densities occurred in July (1.33 individuals $\left./ \mathrm{m}^{2}\right)$, at the beginning of the dry season and in December (1.66 individuals $/ \mathrm{m}^{2}$ ), at the beginning of the rainy season. The morphometric analysis for separate and grouped sexes resulted in negative and positive allometric growth. Ovigerous females were observed in all months, indicating continuous reproduction and the majority (67.81\%) was caught during the less rainy season. The abundance and continuous reproduction of $M$. amazonicum show that this estuary offers conditions for the proper development of this population.
\end{abstract}

Key words: Amazonia, ecology, freshwater shrimp.

\section{INTRODUCTION}

The Amazon shrimp Macrobrachium amazonicum (Heller, 1862) occurs in various habitats, from inland waters (lentic and lotic environments) to estuaries (OdinetzCollart, 1991). This great environmental plasticity of the species has been related to intraspecific differences ranging from morphological characteristics (Porto, 2004) to genetic variations (Peixoto, 2002; Pileggi and Mantelatto, 2010; Vergamini et al., 2011) which might reflect specific conditions of survival, development, reproduction, growth, and relationship to the environmental variables.

Macrobrachium amazonicum is widely distributed in South America, including the Orinoco River basin and the Amazon River up to the Paraguay River basin (Holthuis, 1952), as well as in Guyana, Venezuela, Colombia, Bolivia, Peru, Ecuador, Argentina and Paraguay (Coelho and Ramos Porto, 1985; García-Dávila and Magalháes, 2003; Pileggi et al., 2013). Although investigations have been conducted to elucidate the relative growth patterns of the species, most of the studies have 
focused on artificial environments (Coelho et al., 1982; Lobão et al., 1996; Moraes-Riodades and Valenti, 2002; Moraes-Valenti and Valenti, 2007; Marques et al., 2012). Relative growth in natural populations are poorly known (Flexa et al., 2005; Silva et al., 2007; Bentes et al., 2011; Freire et al., 2012) and the available data are not yet sufficient for a satisfactory comprehension of the plasticity of the species in relation to environmental changes in the many Amazon ecosystems (Maciel and Valenti, 2009).

Assessments of the population structure of shrimps are indispensable in understanding the various relationships that different populations may provide in relation to environmental conditions and this can be evaluated from changes related to growth, sex ratio and reproduction. The species can show wide variations in their population pattern with respect to various factors such as modified environmental conditions, density changes and genetic characteristics, among others (Fonteles Filho, 1989).

Considering the wide ecological and morphological variability of $M$. amazonicum is essential to understand the life cycle of different populations in natural environment. Despite the growing scientific progress in this area, there are still several biological issues to be studied among decapods, as populations' aspects that provides important information for understanding the dynamics of species and helps preserve biodiversity (Mantelatto and Barbosa, 2005). This study aimed to estimate the density and calculate the sex ratio of $M$. amazonicum, as well as investigating the relative growth of the cephalothorax length (CL) with the total length (TL) and the total mass (TM) of shrimps in the fluvial-estuarine plain of northern Brazil.

\section{Material And Methods}

Two sites were chosen for this study: Arapiranga Island ( $01^{\circ} 19^{\prime} \mathrm{S}$ and $\left.48^{\circ} 33^{\prime} \mathrm{W}\right)$ and Mosqueiro Island (Marinhas Channel) $\left(01^{\circ} 10^{\prime} \mathrm{S}\right.$ and $\left.48^{\circ} 19^{\prime} \mathrm{W}\right)$, which is about $70 \mathrm{~km}$ from the city of Belém, State of Pará (Fig. 1). Both sites are relatively preserved with native vegetation on the margins and similar hydrodynamics

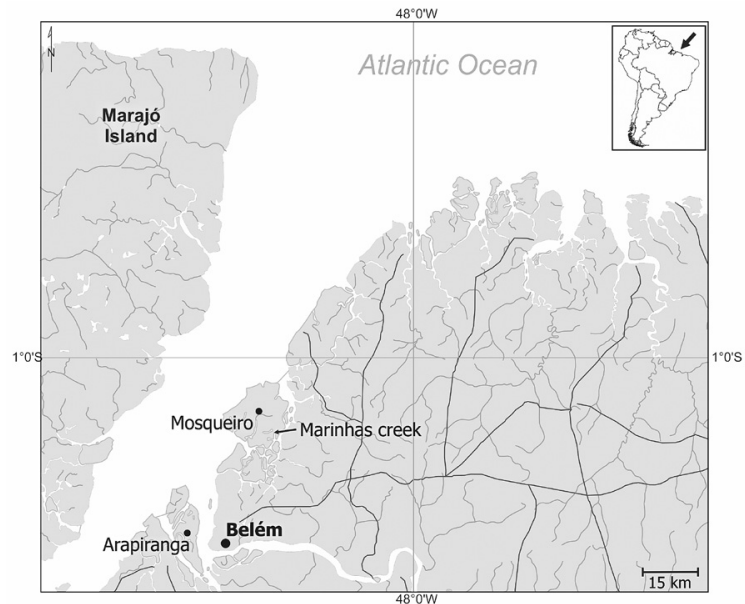

Figure 1. Map showing the sites of collection: Arapiranga Island and Mosqueiro Island (Furo das Marinhas), Amazon estuary of Pará.

conditions. These islands compose the region of the estuary Guajará Bay, a place composed of many channels that constitute a dendritic drainage system containing slightly acidic waters, low transparency and wide variation in quantity of dissolved salts getting lot of oceanic sediment and fluvial origin (Paiva et al., 2006). The bottom is muddy (silt and clay), prevalent in these locations (Gregório and Mendes, 2009).

In the State of Pará, annual rainfall variations determine two distinct climatic periods: a) rainy, with the highest rainfall rates between December and May (mean pluviosity of $983 \mathrm{~mm}$ ) and b) less rainy, between June and November, with mean pluviosity of 60 mm (Moraes et al., 2005).

Shrimps were collected monthly from August 2006 to July 2007, using a manual trawl net $2.60 \mathrm{~m}$ long, with $1.80 \mathrm{~m}$ height, $5.60 \mathrm{~m}$ wide opening, and $15 \mathrm{~mm}$ mesh size (opposed nodes), with wooden rods used as support for handling the net by two people. The net was trawled for a standardized distance of $100 \mathrm{~m}$ for each sample unit. Three trawls were performed per month on each site, totaling 72 sample units (2 sites $\mathrm{x} 12$ months $\mathrm{x}$ three replicates) collected at ebb tide in the new moon and during the day in sediment composed predominantly of fine sand, silt and clay.

Shrimps were identified according to Cervigón et al. (1992) and Melo (2003) and sexed considering the number of appendages 
on the second pair of pleopods as reference (two in males and one in females). Very small shrimps in which it was not possible to observe the secondary sex characters were classified as indeterminate. Total length (TL), from the tip of the rostrum to the end of the telson, and the cephalothorax length (CL), from the orbital cavity to the posterior margin of the carapace, were measured in each specimen with the aid of a digital caliper $(0.01 \mathrm{~mm}$ precision $)$, total wet mass (TM) was measured with a digital scale $(0.01 \mathrm{~g})$.

The density of shrimps was expressed in number of individuals per square meter (ind. $/ \mathrm{m}^{2}$ ), and the swept area (A) was obtained from the formula: $A=N O \times D C$, in which $\mathrm{NO}=$ width of net opening $(5.60 \mathrm{~m})$ and $\mathrm{DC}=$ standardized distance covered in meters $(100 \mathrm{~m})$, totaling $560 \mathrm{~m}^{2}$. The shrimps of the two study sites were pooled for analysis because evidence suggests that they belonged to the same population of $M$. amazonicum. Geographically, the regions of collections are very close to each other and there are no geographical barriers. Moreover, the genetic variability of the species in Pará suggest that no genetic differences are able to structure distinct populations in these environmental conditions (Blank, 2013) and the work of Vergamini et al. (2011) only identifies differences between coastal and continental populations of this species.

The relationships between TM and CL and between TL and CL were described using the BioEstat software, version 5.0 (Ayres et al., 2007) through regression analysis, in which data were logarithmized to obtain the linear function. The type of growth investigated, regarding the relationships between length (TL $\mathrm{x}$ CL) and mass (TM x CL), was determined by the value of the coefficient " $b$ ", obtained by using the following linear equation: $Y=a+b . X$, where: $\mathrm{Y}=\log \mathrm{TL}$ and mass; $\mathrm{X}=\log \mathrm{CL}$; $\mathrm{a}=$ intersection on the $\mathrm{Y}$ axis, when $\mathrm{X}=0 ; \mathrm{b}=$ slope of the straight line or constant rate of $Y$ variation as a function of $\mathrm{X}$. The relationship between the variables determines whether the parts of the body grow proportionally (isometric) in which $b=1$ (for TL $x$ CL) or $b=$ 3 (for TM x CL), or if a body part grows more or less in proportion to the other (allometry). When the variable $\mathrm{Y}$ analyzed varies to a lesser proportion than $\mathrm{X}$, it characterizes negative allometry, i.e., $\mathrm{b}<1$ or $\mathrm{b}<3$. Otherwise, there is a positive allometry $(b>1$ or $b>3$ ) (Hartnoll, 1982). The condition of the coefficient " $b$ " of the linear relationships for males and females was tested by Student's $t$-test. For this analysis, we only used intact shrimps, in order to avoid errors of estimation in case that part of the body could have been damaged.

The null hypothesis of equal sexual proportion was tested by $\mathrm{x}^{2}$ (Chi-square). The normality and the homocedasticity of the variables studied were assessed with ShapiroWilk and Bartlett's tests, respectively. However, even after mathematical transformations, the results did not match the assumptions of parametric tests. A significance level of $95 \%$ was adopted for all tests.

\section{RESUlTS}

Collected shrimps totaled 5,510 of which 91.01\% (5,016) were from Arapiranga Island and 8.99\% (495) from Mosqueiro Island. Considering the shrimps from the two islands, the density of $M$. amazonicum was higher in July $\left(1.33\right.$ ind. $\left./ \mathrm{m}^{2}\right)$, at the beginning of the less rainy period, and in December (1.66 ind./ $\mathrm{m}^{2}$ ), at the beginning of the rainy season. The lowest densities occurred in January (0.31 ind. $/ \mathrm{m}^{2}$ ) and March (0.37 ind. $\left./ \mathrm{m}^{2}\right)$ (Fig. 2).

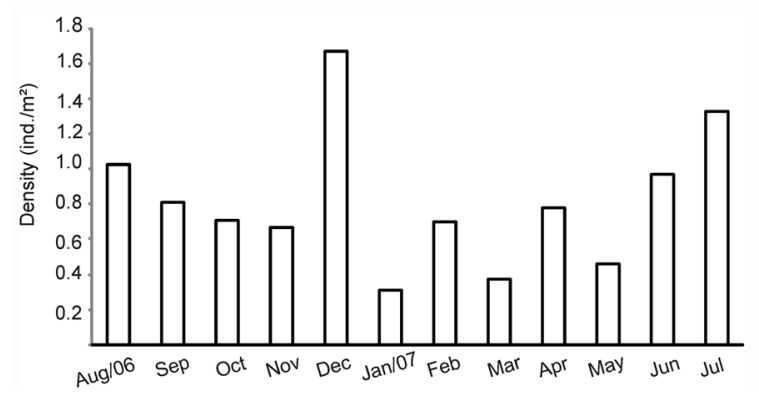

Figure 2. Density of $M$. amazonicum from August 2006 to July 2007, on Mosqueiro Island and Arapiranga Island, Amazon estuary of Pará. 
A total of 2,829 females (51.34\%), 2,659 males (48.25\%) and 22 (0.39\%) indeterminate sex were captured. The total proportion of male:female (0.94:1) was not statistically significant $(\mathrm{p}>0.05)$. Males were more frequent in classes between 9 and 11 $\mathrm{mm}$ of CL, while the majority of females were in classes 12 to $14 \mathrm{~mm}$ of CL (Fig. 3). With the exception of the $12 \mathrm{~mm}$ class, the classes of length between 9 and $21 \mathrm{~mm}$ showed no significant difference regarding the sexual proportion (Fig. 3). Mean values of CL (11.75 $\pm 1.5 \mathrm{~mm})$, average TL $(55.83 \pm 12.8 \mathrm{~mm})$ and TM $(1.57 \pm 1,53 \mathrm{~g})$ of males were smaller than those of females (CL: $13.44 \pm 2.97 \mathrm{~mm}$, TL: $59.33 \pm 13.22 \mathrm{~mm}$ and TM: $2.09 \pm 1.42 \mathrm{~g}$ ) (CL: $\mathrm{t}=15.89, \mathrm{p}<0.001 ; \mathrm{TL}: \mathrm{t}=10.99$, $\mathrm{p}<0.001)$.

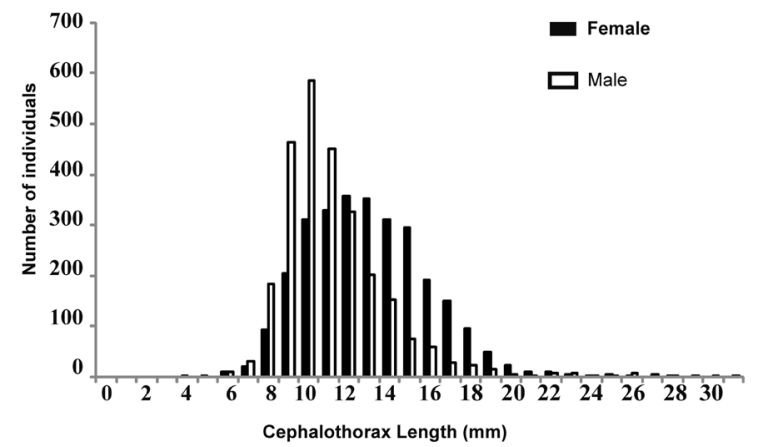

Figure 3. Distribution of cephalothorax length class of $M$. amazonicum captured from August 2006 to July 2007 on Arapiranga Island and Mosqueiro Island, Amazon estuary of Pará.

Ovigerous females were found in every month. We found 319 ovigerous females of M. amazonicum, which represent $11.31 \%$ of the total of females. The highest proportion $(67.81 \%)$, occurred during the less rainy season and $103(32.19 \%)$ in the rainy season. March and October were the months of highest incidence of ovigerous females in relation to non-ovigerous females (Fig. 4).

The relation $\mathrm{TL} \times \mathrm{CL}$ had positive allometry $(b>1)$, i.e., the growth of TL was greater in relation to the proportional growth of the cephalothorax for both sexes, separated and together (Fig. 5). Negative allometry $(\mathrm{b}<3)$ was found for the relation between mass (TM) and CL for the sexes together and for males and females separately (Fig. 6). The coefficient "b" did not differ significantly between the sexes regarding the relation TL $\mathrm{x} C L$ and it was only significant for TM x CL $(t=3.03, p<0.05)$.

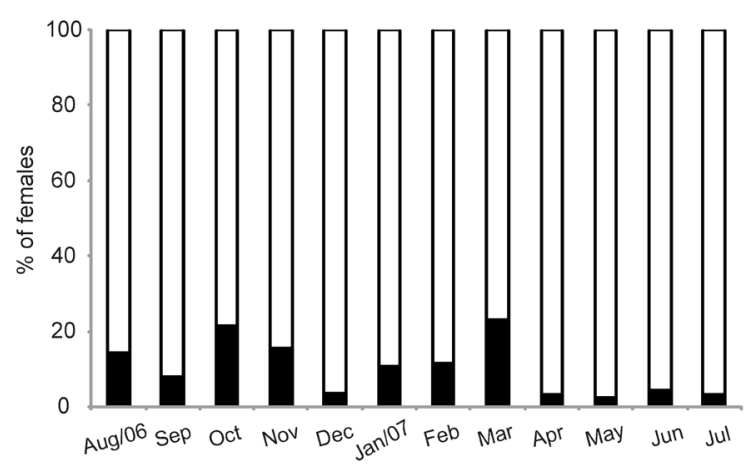

Figure 4. Proportion of ovigerous females of $M$. amazonicum captured from August 2006 to July 2007 on Mosqueiro Island and Arapiranga Island, Amazon estuary of Pará. Black bar: ovigerous female, white bar: non-ovigerous females.

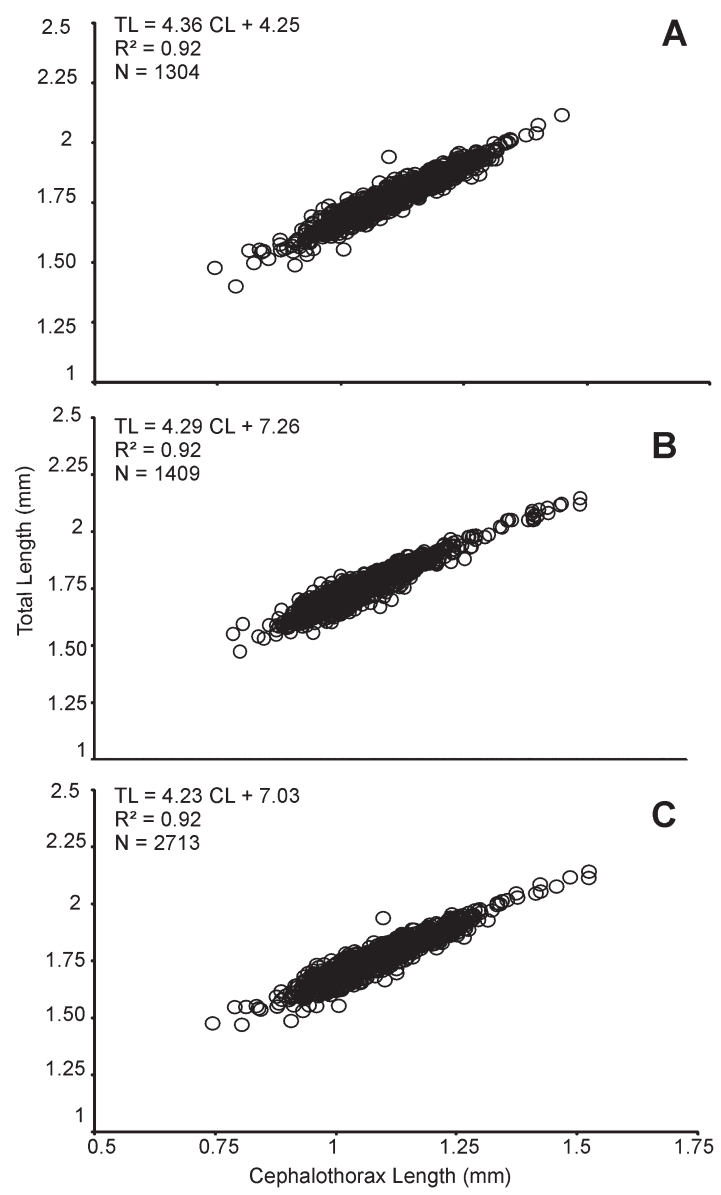

Figure 5. Relationship between cephalothorax length (CL) and total length (TL) $(\mathrm{mm})$ of $M$. amazonicum, captured from August 2006 to July 2007 on Mosqueiro Island and Arapiranga Island, Amazon estuary of Pará. A = females, B = males, and $\mathrm{C}=$ sexes together. 


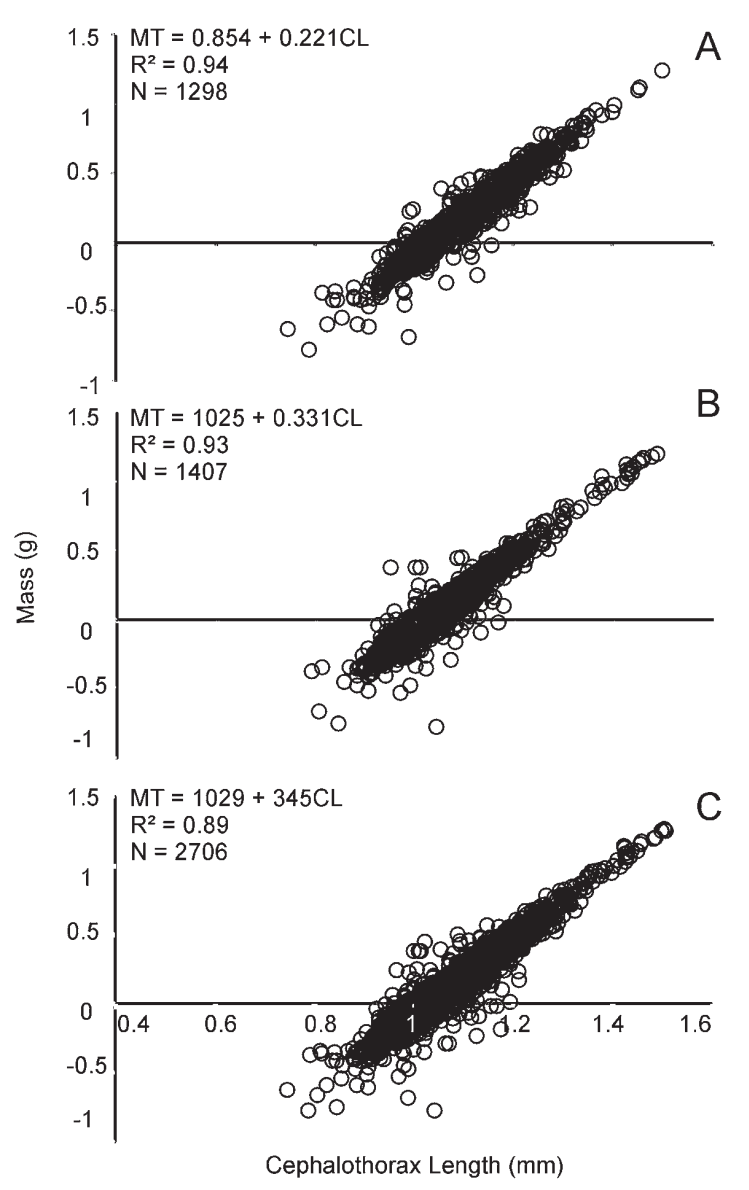

Figure 6. Relationship between body mass (g) and cephalothorax length (CL) ( $\mathrm{mm}$ ) of $M$. amazonicum, captured from August 2006 to July 2007 on Mosqueiro Island and Arapiranga Island, Amazon estuary of Pará. A = females, B = males, and $\mathrm{C}=$ sexes together.

\section{Discussion}

The highest densities of $M$. amazonicum occurred in the less rainy season, probably due to the smaller volume of water that decreases the area of occupancy of the species (OdinetzCollart and Moreira, 1993). There is high amount of material in suspension during the rainy season in the Guajará Bay (Pará) due to high rainfall. Consequently, the phytoplankton is reduced during this period because there is little light penetration (Paiva et al., 2006). Therefore, the decrease of $M$. amazonicum at this time can be caused by reduced availability of food for the larvae. Another factor that may contribute to these results is that the volume of water in the rainy season is increased by decreasing the catchability of shrimp during this period.

Overall sex-ratio of $M$. amazonicum that did not differ significantly from the expected
1:1 was also verified by Flexa et al. (2005), Sampaio et al. (2007) and Silva et al. (2007). The ovigerous females of $M$. amazonicum were found throughout the year; indicating continuous reproduction, as also observed by Odinetz-Collart (1991) in the lower Amazon region, Peixoto (2002), Lucena-Frédou et al. (2010) and Freire et al. (2012).

The highest numbers of ovigerous females of $M$. amazonicum were found in March and October, being more frequent in the less rainy period when the seawater enters the estuary, which is an important condition for larval development (Guest and Durocher, 1979; Lobão et al., 1987). This pattern diverges from several studies that reported a peak in reproduction only in the rainiest seasons in different regions of Brazil, as well as in other Amazon regions (Odinetz-Collart, 1991), Northeast (Bragagnoli and Grotta, 1995; Sampaio et al., 2007), Midwest (Porto, 1998) and South (Bialetzki et al., 1997). Several environmental factors contribute to reproduction of estuarine shrimp, such as temperature, sediment, salinity and rainfall (Pinheiro and Hebling, 1998). However, in areas of study such factors do not seem to exert influence on the reproductive cycle of $M$. amazonicum. The highest peak of ovigerous females in the middle of the distinct seasons suggests a relationship with the strongest currents which occur in these periods, because, according to Lucena-Frédou et al. (2010), the main stimulus for reproduction seems to be the current velocity and the availability of food, due to the greater dispersion of larvae promoted by these strong currents, increasing the occupancy in a greater number of habitats.

Macrobrachium amazonicum showed higher growth in total length than in cephalothorax length, since the latter grew more in proportion compared to increase in mass. The positive allometry of the TL may be due to the increase of females' abdomen to maximize reproduction, providing a larger surface for adherence of eggs (Silva et al., 2007). According to Moraes-Riodades and Valenti (2002) in a study about $M$. amazonicum in shrimp farms, this pattern is justified since 
the cephalothorax contains most of the shrimp's vital organs (heart, stomach, gonads and gills). This pattern of lengths of relative growth obtained in this study corroborate those found by Lobão et al. (1996), which analyzed the species in captivity, Flexa et al. (2005) in Cametá (Pará), Silva et al. (2007) on Combu Island, Bentes et al. (2011) in the Guajará estuary (Pará) and Freire et al. (2012) in an estuary in northeast Pará. However, the relationship mass/length of the cephalothorax also showed negative allometry, which is a pattern widely reported in the literature on Palaemonidae (Flexa et al., 2005; Silva et al., 2007).

Coefficient "b" was significantly different $(\mathrm{p}<0.05)$ between males and females with regard to variables TM x CL, revealing a possible sexual dimorphism. The existence of a size difference between the sexes without any difference in mass between males suggests that they may have had a mass gain in body parts (eg., Sequelae) which is not reflected in overall size. This result was also found by Flexa et al. (2005) studying the population of Macrobrachium amazonicum in Cametá (Pará); Mantelatto and Barbosa (2005) studying Macrobrachium brasiliense (Heller, 1862) in the inland waters of the State of São Paulo; and Collins (2001) investigating M. borelli (Nobili, 1896) in the Paraná River.

Males of $M$. amazonicum were smaller in CL and TL than those of females, which is a pattern similar to that found by Bentes et al. (2011) in the same estuary, though using passive fishing gear (matapi trap). Males are more susceptible to predation and fishing; therefore, they had lower average sizes, while females can adopt cryptic habits for protection of offspring and the larger size of females may reflect a breeding strategy for ensuring more eggs attached to the pleopods, thereby increasing the chances of survival (Bentes et al., 2011). Females attain larger sizes because of the space required to store reserves, offspring and eggs (Magalhães and Walker, 1988). These body size patterns of males and females corroborate with the work of Silva et al. (2002) in the Vigia estuary (PA), Flexa et al. (2005) and Bentes et al. (2011). The study of species held by Odinetz-Collart and Moreira (1993) and Silva et al. (2007) in the Amazon basin also reveal larger lengths of females, which denotes a pattern for Amazon populations. Mantelatto and Barbosa (2005) demonstrate the inverse for $M$. brasiliense in inland waters of the State of São Paulo, as well as Mattos and Oshiro (2009) for Macrobrachium potiuna (Muller, 1880) in Rio de Janeiro. The authors suggest that males are larger in order to exert dominance during copulation. Similar results were found by Flexa et al. (2005), Bentes et al. (2011) and Freire et al. (2012).

Changes in weight of shrimps may be associated with metabolism, energy output or stomach contents (Silva et al., 2007). Although males were smaller than females, the sexes did not differ in mass, probably due to males gaining mass in other body structures, such as chelipeds, which are more robust. Although the species present patterns that corroborate most studies in estuarine environments, especially in relation to growth and abundance, there are still differences of others, demonstrating that their population aspects are peculiar in the estuary Guajará, reinforcing its high environmental plasticity.

The information on population structure obtained in this study serves as a baseline for future comparisons of natural populations of other regions, as well as farmed shrimp populations. Due to the high economic potential and ecological importance of $M$. amazonicum, further studies are needed for a better understanding of the species in the natural environment in order to subsidize conservation strategies, since it is a target species of small-scale fishing in the Amazon region and there is no fishing regulation for this resource.

ACKNOWLEDGEMENTS - We are especially grateful to the Federal University of Pará (UFPA) for providing the necessary infrastructure; to the Conselho Nacional de Desenvolvimento Científico e Tecnológico - $\mathrm{CNPq}$ for the funding (Public Notice 032/2005 CT-Amazônia) and for the scholarship granted by the Institutional 
Program of Scientific Initiation Scholarships (PIBIC/ $\mathrm{CNPq}$ ) to the first author of this study. We are also thankful to our colleagues of the Laboratory of Fisheries Biology and Aquatic Resources Management and the Research Group in Crustaceans Ecology in the Amazon (GPECA) for their support during field collections. This work was conducted under IBAMA License No. 02018.00729/06-36 and received support for the production of the English version by Eduardo Gentile, through the Public Notice PAPQ, PROPESP/FADESP of the Federal University of Pará.

\section{REFERENCES}

Ayres, M.; Ayres Jr, M.; Ayres, D.L. and Santos, A.S. 2007. BioEstat 5.0 Aplicaçôes estatísticas nas áreas das Ciências Biológicas e Médicas. Instituto de Desenvolvimento Sustentável Mamirauá/MCT/ CNPq, 364p.

Bentes, B.; Martinelli, J.M.; Souza, L.S.; Cavalcante, D.V; Almeida, M.C. and Isaac, V.J. 2011. Spatial distribution of the Amazon River Shrimp Macrobrachium amazonicum (Heller, 1862) (Decapoda, Caridea, Palaemonidae) in two perennial creeks of an estuary on the northern coast of Brazil (Guajará Bay, Belém, Pará). Brazilian Journal of Biology, 71(4): 925-935.

Blank, D.V. 2013. SNPs no gene da HSC70 e suas implicaçóes na carcinicultura e conservação dos estoques de camarão-da-Amazônia (Macrobrachium amazonicum). Universidade Federal de Sáo Carlos, São Paulo, Brazil. Ph.D. Thesis. 151p. [Unpublished].

Bialetzki, A.; Nakatani, K.; Baumgartner, G. and BondBuckup, G. 1997. Occurrence of Macrobrachium amazonicum (Heller, 1862) (Decapoda, Palaemonidae) in Leopoldo's Inlet (Ressaca do Leopoldo), upper Paraná River, Porto Rico, Paraná, Brasil. Revista Brasileira de Zoologia, 14(2): 379-390.

Bragagnoli, G. and Grotta, M. 1995. Reprodução do camarão de água-doce Macrobrachium amazonicum no açude Epitácio Pessoa, Boqueirão (PB), Brasil. Revista Nordestina de Biologia, 10(2):141-154.

Cervigón, F.; Cipriano, R.; Fisher, W. and Garibaldi, L. 1992. Guia de campo de las especies comerciales marinas y de águas salobres da La Costa Septentrional de Sur America. Organização das Nações Unidas para a Agricultura e Alimentação, Roma, Itália, $512 \mathrm{p}$.

Coelho, P.A.; Ramos Porto, M. and Soares, C.M.A. 1982. Crescimento em viveiro de cultivo do camarão canela Macrobrachium amazonicum (Decapoda, Palaemonidae). Revista Brasileira de Zoologia, 1(1): 45-49.

Coelho, P.A. and Ramos-Porto, M.R. 1985. Camaróes de água doce do Brasil: Distribuição Geográfica. Revista Brasileira de Zoologia, 2(6): 405-410.

Collins, P. 2001. Relative growth of the fresh water prawn Macrobrachium borelli (Nobili, 1896) (Decapoda, Palaemonidae). Nauplius, 9(1): 53-60.

Flexa, C.E.; Silva, K.C.A. and Cintra, I.H.A. 2005. Morfometria do camarão-cascudo Macrobrachium amazonicum (Heller) no município de Cametá Pará. Boletim Técnico-Cientifico do CEPNOR, 5(1): 41-54.

Fonteles-Filho, A.A. 1989. Recursos Pesqueiros: biologia e dinâmica populacional. Imprensa Oficial do Ceará, Fortaleza, Ceará, 296p.
Freire, J.L.; Marques, C.B. and Silva, B.B. 2012. Estrutura populacional e biologia reprodutiva do camarão-da-Amazônia Macrobrachium amazonicum (Heller, 1862) (Decapoda: Palaemonidae) em um estuário da regiāo nordeste do Pará, Brasil. Brazilian Journal of Aquatic Science and Technology, 16(2): 6576.

García-Dávila, C.R. and Magalhães, C. 2003. Revisão taxonômica dos camaróes de água doce (Crustacea: Decapoda: Palaemonidae, Sergestidae) da Amazônia peruana. Acta Amazonica, 33(4): 663-686.

Gregório, A.M.S. and Mendes, A.C. 2009. Characterization of sedimentary deposits at the confluence of two tributaries of the Pará River estuary (Guajará Bay, Amazon). Continental Shelf Research, 29: 609-618.

Guest, W.C. and Durocher, P.P. 1979. Palaemonidae shrimp, Macrobrachium amazonicum: effects of salinity and temperature on survival. Progressive Fish-culturist, 41: 14-18.

Hartnoll, R.G. 1982. Growth. In: Bliss, D.E. (ed.), The Biology of Crustacea. Embriology, Morphology and Genetics. New York: Academic Press, Vol. 2, 382p.

Holthuis, L.B. 1952. A general revision of the Palaemonidae (Crustacea Decapoda Natantia) of the Americas. II. The subfamily Palaemoninae. Occasional Paper 12, Allan Hancock Foundations Publications, 396p.

Lobão, V.L.; Rojas, N.E.T.; Barros, H.P.; Lace, M.; Horikawa, M.T. and Lula, L.A.B.M. 1987. Determinaçáo de densidades adequadas para a larvicultura de Macrobrachium amazonicum (Heller, 1862) (Crustacea, Decapoda, Palaemonidae). Boletim do Instituto de Pesca, 14: 45-49.

Lobão, V.L.; Roverso, E.A.; Lace, M. and Hortênsio, M. 1996. Ciclo de muda e crescimento em Macrobrachium amazonicum (Heller, 1862) e Macrobrachium rosenbergii (De Man) (Decapoda, Palaemonidae). Boletim do Instituto de Pesca, 23: 3145.

Lucena-Frédou, F.; Rosa Filho, J.S.; Silva, M.C.M. and Azevedo, E.F. 2010. Population dynamics of the river prawn Macrobrachium amazonicum (Heller, 1862) (Decapoda, Palaemonidae) on Combú island (Amazon estuary). Crustaceana, 83(3): 277-290.

Maciel, C.R. and Valenti, W.C. 2009. Biology, Fisheries, and Aquaculture of the Amazon River Prawn Macrobrachium amazonicum: a review. Nauplius, 17(2): 61-79.

Magalhães, C. and Walker, I. 1988. Larval development and ecological distribution of Central Amazonian Palaemonidae shrimp (Decapoda, Caridea). Crustaceana, 55(3): 279-292.

Mantelatto, F.L. and Barbosa, L.R. 2005. Population structure and relative growth of freshwater prawn Macrobrachuim brasiliense (Decapoda, Palaemonidae) from São Paulo State, Brazil. Acta Limnologica Brasiliense, 17(3): 245-255.

Marques, H.L.A.; Barros, H.P.; Mallasen, M.; Boock, M.V. and Moraes-Valenti, P.C.A. 2012. Influence of stocking densities in the nursery phase on the growth of Macrobrachium amazonicum reared in net pens. Aquaculture, 307: 240-245.

Mattos, L.A. and Oshiro, L.M.Y. 2009. Estrutura populacional de Macrobrachium potiuna (Crustacea: Palaemonidae) no Rio do Moinho, Mangaratiba, Rio de Janeiro, Brasil. Biota Neotropica, 9(1): 81-86. 
Melo, G.A.S. 2003. Manual de identificação dos Crustacea Decapoda de água doce do Brasil. São Paulo, Editora Plêiade, 430p.

Moraes, B.C.; Costa, J.M.N.; Costa, A.C.L. and Costa, M.H. 2005. Variação espacial e temporal da precipitação no estado do Pará. Acta Amazonica, 35(2): 207-214.

Moraes-Riodades, P.M.C. and Valenti, W.C. 2002. Crescimento relativo do camarão canela Macrobrachium amazonicum (Heller) (Crustacea, Decapoda, Palaemonidae) em viveiros. Revista Brasileira de Zoologia, 19(4): 1169-1176.

Moraes-Valenti, P.M.C. and Valenti, W.C. 2007. Effect of intensification on growth out of the Amazon river prawn, Macrobrachium amazonicum. Journal of the World Aquaculture Society, 38(4): 516-526.

Odinetz-Collart, O. 1991. Ecologia e Potencial Pesqueiro do camarão-canela, Macrobrachium amazonicum na Bacia Amazônia. In: E.J.F. Fereira; G.M. Santos, E.L.M. Leão and L.A. Oliveira (eds), Bases científicas para estratégias de preservação e desenvolvimento da Amazônia. Fatos e Perspectivas, Vol. 2., Manaus, INPA.

Odinetz-Collart, O. and Moreira, L.C. 1993. Potencial pesqueiro do camarão-canela, Macrobrachium amazonicum na Amazônia Central (Ilha do Careiro): variação da abundância e do comprimento. Amazoniana, 12 (3/4): 399-413.

Paiva, R.S.; Esquinazi-Leça, E.; Passavante, J.Z.O.; Silva-Cunha, M.G.G. and Melo, N.F.A.C. 2006. Consideraçóes ecológicas sobre o fitoplâncton da baía do Guajará e foz do Rio Guamá (Pará, Brasil). Boletim Museu Emílio Goeldi, sér. Ciências Naturais, 2(2): 133-146.

Peixoto, S.N.B. 2002. Caracterização molecular e biologia reprodutiva de Macrobrachium amazonicum (Crustacea, Decapoda, Palaemonidae). Braganca, Universidade Federal do Pará - UFPA, Master Dissertation, 71 pp. [Unpublished].

Pileggi, L.G. and Mantelatto, F.L. 2010. Molecular phylogeny of the freshwater prawn genus Macrobrachium (Decapoda, Palaemonidae), with emphasis on the relationships among selected American species. Invertebrate Systematics, 24(2): 194-208.

Pileggi, L.G.; Magalhães, C.; Bond-Buckup, G. and Mantelatto, F.L. 2013. New records and extension of the known distribution of some freshwater shrimps in Brazil. Revista Mexicana de Biodiversidad, 84(2): 563-574.

Pinheiro, M.A.A. and Hebling, N.J. 1998. Biologia de Macrobrachium amazonicum (De Man, 1879). p. 21-46. In: Valenti, W.C. (ed.), Carcinicultura de água doce: Tecnologia para Produção de Camaróes, São Paulo: FAPESP, Brasília: IBAMA.

Porto, L.A.C. 1998. Estrutura populacional e biologia reprodutiva de Macrobrachium amazonicum (Heller, 1862) (Crustacea, Decapoda), na bacia hidrográfica do rio Meia-Ponte, Bela Vista de Goiás-GO, Brasil. Universidade de São Paulo - USP, Master Dissertation, 117 pp. [Unpublished].

Porto, L.A.C. 2004. Estudos morfológicos em populaçóes do complexo Macrobrachium amazonicum (Heller, 1862) (Crustacea, Decapoda, Palaemonidae) em diferentes bacias hidrográficas brasileiras. Universidade de São Paulo-USP, São Paulo, Brazil, Ph.D. Thesis. 260p. [Unpublished].
Sampaio, C.M.S.; Silva, R.R.; Santos, J.A. and Sales, S.P. 2007. Reproductive cycle of Macrobrachium amazonicum (Crustacea: Palaemonidae) females. Brazilian Journal of Biology, 67(3): 551-559.

Silva, K.C.A.; Cintra, I.H.A.; Souza, R.A.L. and Garrido, P.A.M. 2002. Camaróes capturados em áreas estuarinas no município de Vigia-Pará-Brasil. Boletim Técnico-Cientifico do Cepnor, 2(1): 81-96.

Silva, M.C.N.; Lucena-Frédou, F. and Rosa Filho, J.S. 2007. Estudo do crescimento do camaráo Macrobrachium amazonicum (Heller, 1862) da Ilha do Combu, Belém, Estado do Pará. Amazônia, Ciência \& Desenvolvimento, 2(4): 85-104.

Vergamini, F.G.; Pileggi, L.A.G. and Mantelatto, F.L. 2011. Genetic variability of the Amazon river prawn Macrobrachium amazonicum (Decapoda, Caridea, Palaemonidae). Contributions to Zoology, 80(1): 6783. 